\title{
Questions fly over ash-cloud models
}

Scientists have leapt to defend the predictions made by their models of volcanic ash dispersal, the results of which grounded more than 100,000 flights across Europe this month over fears about safety. But with Europe's airspace virtually paralysed for six days, the real question now is precisely how much ash can a jet engine safely tolerate?

With planes once again flying after the biggest disruption to European aviation in decades, critics have been quick to dispute the model used by the Met Office's London Volcanic Ash Advisory Centre, responsible for predicting the movement of ash cloud from the Icelandic volcano Eyjafjallajökull.

Researchers say that their model tracked the cloud successfully: "I would completely defend the model as correct," says Derrick Ryall, head of the Met Office's climate programme. But critics argue that it overestimated the extent of the ash cloud, and therefore gave the impression that the risk to aircraft was far greater than in reality. "We must make decisions based on the real situation in the sky, not on theoretical models," said Giovanni Bisignani, director-general and chief executive of the International Air Transport Association, the global trade organization for airlines, on 19 April.

The atmospheric dispersion model under fire was originally developed to track radioactive fallout from the Chernobyl nuclear disaster in 1986. This nuclear accident model (NAME) calculates how particles spread through the atmosphere how far, how fast and how high - based on information about wind speed and direction, along with data about the concentration, composition and size of the ash particles.

During the days after the eruption in Iceland, a barrage of research showed the ash plume spreading as the model predicted. Ground-based laser ranging picked out clumps of ash; satellite images tracked the overall plume; and research aircraft sampled the plume directly.

"I don't see that the model has not done what it's supposed to do," says Hugh Coe, an atmospheric scientist at the University of Manchester, $\mathrm{UK}$, and chair of aircraft operations at the Met Office's Facility for Airborne Atmospheric Measurements (FAAM) at Cranfield, near Bedford, UK. "The observations so far have been consistent with the predicted plumes," agrees Ryall, who helped to develop NAME.

Despite the model's success, the question of how much ash is unsafe remains unanswered. "One of the problems is that we don't know what level of ash concentration is hazardous to aircraft," says Fred Prata, senior scientist with the Climate and Atmosphere Department of the Norwegian Institute for Air Research near Oslo, who has been investigating volcanic ash for more than 20 years. He is frustrated that, until now, airlines and engine manufacturers have been reluctant to commission studies on the impact of ash on their aircraft. In 1991, Prata suggested that a monitor on board an aircraft could link with radar data so that pilots could detect and steer around ash hazards

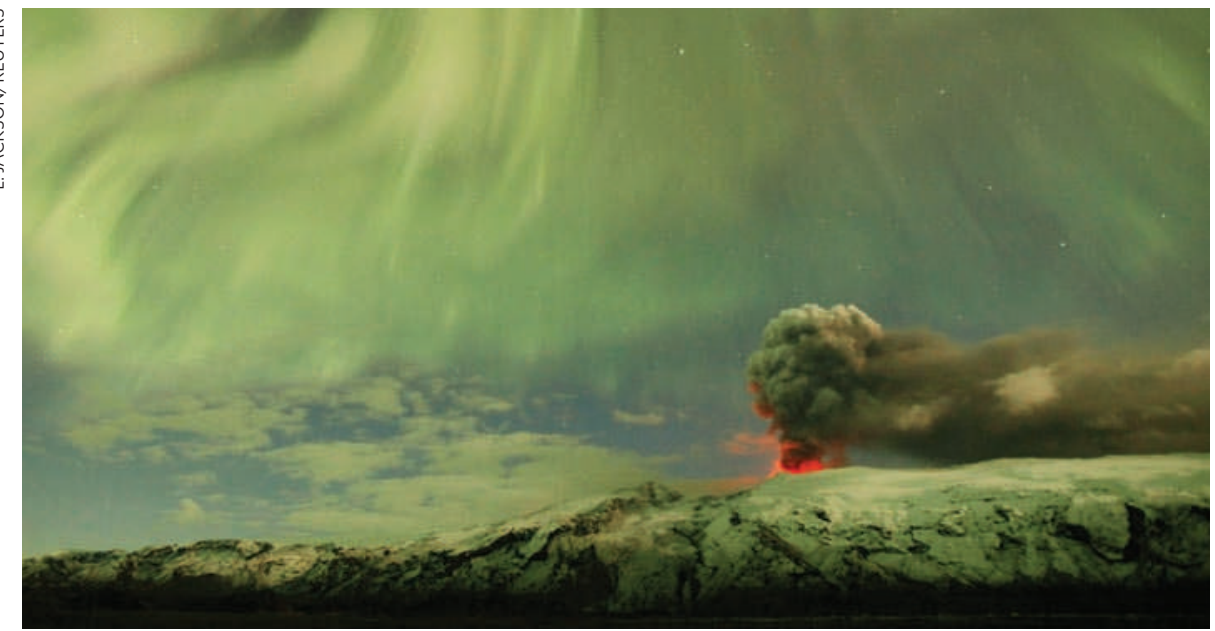

The Icelandic volcano Eyjafjallajökull, still spewing ash, beneath the eerie light of the aurora borealis.
(A. J. Prata et al. Nature 354, 25; 1991). But the device was never developed. "Planes would be flying if they had this," he told Nature at the height of the crisis last week.

Ulrich Schumann, director of the Institute of Atmospheric Physics at the German Aerospace Centre (DLR) near Munich which sent up a research flight to sample ash over Germany and the Netherlands on 19 April - says that on the basis of that evidence, grounding flights was the correct decision. International aviation guidelines recommend that no planes should fly though airspace that contains volcanic ash. from two incidents in the 1980 s that saw airborne volcanic ash shut down the engines of passenger jets. But Denis Chagnon, a spokesman for the International Civil Aviation Organization (ICAO), insists that this approach is merely "guidance", not an international regulation.

Flights were restarted in Europe last week once Britain's Civil Aviation Authority declared that airspace with less than 2,000 micrograms of dust per cubic metre was safe after all, based on test flights conducted by the aviation industry. "At these levels, you'd be flying in fairly thick goo," says Coe. The DLR research flight found concentrations of just 60 micrograms of ash per cubic metre, and the latest information from the FAAM's two aircraft shows that the ash plume is dominated by relatively tiny particles measuring just 0.1 micrometres in diameter, although most of the plume's mass comes from particles measuring 3 micrometres across. Such microscopic measurements can help to predict the plume's long-distance reach, because smaller ash particles can travel much farther than larger ones. Understanding the plume's composition could also help to estimate how much ash might actually get into a jet engine, but there has been little research on such questions.

The ICAO says that it will now set up a multidisciplinary team as a matter of urgency to address how to handle a similar situation in future, and to try to determine a threshold for safe aircraft operation in volcanic ash.

"If the world wants to move forward, maybe we want to research better what is safe," says Ryall.

Katharine Sanderson 